\title{
Sosialisasi Sistem Penerangan Listrik dan Perhitungan Tarif Listrik Tahun 2020 pada Pemuda Muhammadiyah Cabang Pulo Brayan Darat
}

\author{
Abdullah, Cholish, Moh. Zainul Haq, Ferdinan Rinaldo Tampubolon, Rischa Devita \\ Jurusan Teknik Elektro, Politeknik Negeri Medan \\ Email: cholish@polmed.ac.id
}

\begin{abstract}
The increasing use of electrical energy in society in 2020 is closely related to the pandemic problem that is occurring. Increased household activity causes a surge in energy in the household sector. This increase in energy consumption needs to be balanced by providing exposure to the utilization of existing electrical equipment in households. The lighting system give an important role in energy consumption in the household sector. The dedication carried out is by providing knowledge on the use of the lighting system, the rules in PUIL 2000 and the calculation of the Basic Electricity Tariff (TDL) in 2020. Submission of this will certainly increase public understanding of energy savings so that it can contribute to overcoming the problem of electricity devisit occur.
\end{abstract}

Keywords: lighting system, basic electricity rates, PUIL 2000

\section{Pendahuluan}

Permasalahan energi listrik saat ini merupakan hal yang harus segera diselesaikan ditengah lingkungan pada penduduk yang dalam hal ini dikota medan. Pemuda Muhammadiyah Cabang Pulo Brayan yang sebagian besar berada di sekitar Masjid Taqwa Muhammadiyah Gang Keluarga Kecamatan Medan Timur Kelurahan Pulo Brayan Darat 1. Lokasi tersebut berada dibawah pelayanan PLN Cabang Medan Timur yang memiliki jumlah pelanggan yang cukup besar pada sektor rumah tangga. Permasalahan yang sering terjadi selain tindak pencurian listrik rumah tinggal adalah kurangnya pemahaman masyarakat dalam melakukan pemilihan sistem penerangan sehingga masih banyak yang menggunakan teknologi sistem penerangan lampu jenis lampu pijar dan TL.

Berdasarkan informasi yang diperoleh dari masyarakat disekitar adalah belum mengetahui teknologi serta pemahaman terhadap perhitungan tarif listrik sehingga memberikan rasa ketidaknyamanan dalam pembayaran listrik. Peningkatan tarif listrik pada tahun 2020 sangat membebani masyarakat sehingga perlu adanya pengetahuan ditengah masyarakat mengenai perhitungan penggunaan listrik serta pemilihat sistem penerangan yang sesuai dengan penggunaan yang diharapkan.

Berdasarkan informasi tersebut serta dengan memperhatikan kondisi pada lokasi mitra maka sangat perlu dilaksanakan transfer ilmu pengetahuan dalam Sosialisasi Sistem Penerangan Listrik Dan Perhitungan Tarif Listrik Tahun 2020 Pada Pemuda Muhammadiyah Cabang Pulo Brayan Darat. Program Studi Teknik Listrik Jurusan Teknik Elektro Politeknik Negeri Medan saat ini sangat konsen terhadap penerapan teknologi di tengah masyarakat dengan kemampuan dosen di bidang pengolahan sumber energi.

\section{Solusi}

Pengabdian yang dilaksanakan mengacu pada rencana pelaksanaan kegiatan yang sesuai dengan kondisi yang terdapat di lapangan. Adapun solusi yang dilakukan adalah : 
1. Penerapan teknologi yang dilakukan adalah dengan melakukan pemaparan konsep dan metode dalam memperkenalkan sistem penerangan yang sesuai dengan sistem beban yang digunakan.

2. Dengan membentuk karakter masyarakat yang peduli terhadap penghematan energi listrik maka diharapkan permasalahan akan kesadaran masyarakat terhadap pemanfaatan teknologi sistem penerangan mampu mengurangi permasalahan energi yang terjadi

3. Melakukan sosialisasi mengenai perhitungan tarif dasar listrik pada pemuda dan masyarakat di sekitar Kelurahan Pulo Brayan Darat.

4. Melakukan pengawasan intensif kepada Pemuda dan masyarakat sehingga transfer keilmuan dan teknologi dapat diaplikasikan keseluruh rumah yang berada disekitar pelaksanaan program.

\section{Metode Pelaksanaan}

\subsection{Metode Pendekatan}

Metode pendekatan pada program yang akan dilaksanakan adalah :

a. Melakukan pendataan terhadap warga masyarakat dengan penggunaan sistem penerangan yang.

b. Melakukan pendekatan dengan seluruh warga disekitar guna mendukung keberhasilan program.

c. Melakukan perancangan materi penyampaian yang sesuai dengan sasaran program pengabdian.

\subsection{Prosedur Kerja}

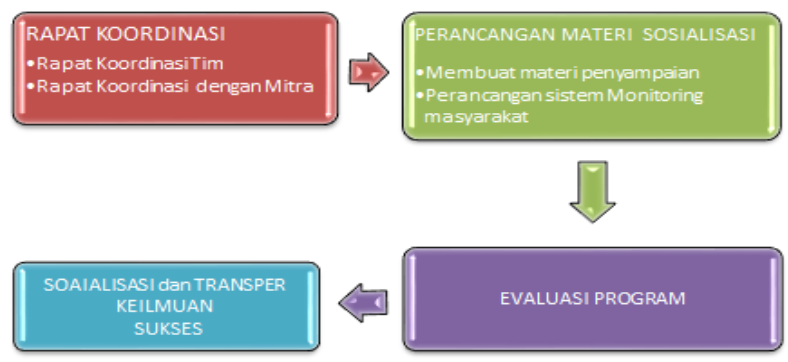

Gambar 1. Tahapan Sosialisasi Program

\subsection{Rencana Kegiatan}

Kegiatan ini akan dilaksanakan sebagai berikut :

a. Tahap Perancangan Program Pengabdian

Tahap awal program pengabdian ini adalah perancangan metode penyampaian materi mengenai sosialisasi sistem penerangan listrik rumah sederhana. Pada tahap ini diharapkan diperoleh rancangan sistem yang baik sehingga memudahkan Tim Lapangan dalam mengembangkan program selanjutnya.

b. Tahap Sosialisasi Program

1. Musyawarah Masyarakat dan Tim Peneliti 
Sosialisasi pelaksanaan berdasarkan perancangan program dilakukan melalui koordinasi Tim Peneliti (Dosen dan Mahasiswa) dengan Pemuda Muhammadiyah Cabang Pulo Brayan Darat mengenai pelaksanaan kegiatan program pengabdian. Melalui proses tersebut diharapkan hasil berupa kesepakatan dalam pelaksanaan kegiatan hingga penyelesaian kegiatan. Kesepakatan akan pentingnya keberlangsungan program akan meningkatkan rasa kepercayaan dari warga persyarikatan terhadap Tim Pengabdian Politeknik Negeri Medan.

2. Pembentukan Tim Lapangan

Data mengenai informasi pemakaian teknologi sistem penerangan listrik rumah tangga yang berasal seluruh warga masyarakat disekitar. Mekanisme pembentukan Tim Lapangan diharapkan dapat membantu penyelesaian pelaksanaan program agar dapat terselesaikan sesuai dengan rencana waktu pelaksanaan program. Tugas yang dilaksanakan adalah membantu mensosialisasikan program serta memberikan informasi yang dibutuhkan berdasarkan parameter yang dibutuhkan program.

3. Sosialisasi

Adapun materi sosialisasi yang akan diberikan adalah :

a. Materi 1 ; Pengantar Teknologi Sistem Penerangan

b. Materi 2 ; Sistem Instalasi Penerangan Listrik dengan Standarisasi PUIL 2000

c. Materi 3 ; Sistem Perhitungan daya Listrik Terhadap Biaya Penggunaan

d. Materi 4 ; Pemanfaatan Tipe Lampu terhadap Aktifitas sehari-hari

Melalui pelatihan tersebut diharapkan pemahaman masyarakat terhadap sistem penerangan listrik menjadi lebih ditingkatkan. Pelaksanaan aktifitas ini sangat penting sehingga maksud dan tujuan pengabdian.

c. Tahap monitoring

Monitoring yang dilakukan berkenaan dengan peningkatan pemahaman serta pelaksanaan sistem penerangan yang sesuai dengan ketentuan yang sesuai Standart Nasional Indonesia. Melalui komunikasi Tim Peneliti dengan Warga masyarakat tersebut dapat menjadi landasan terhadap pengembangan program yang telah dilaksanakan. Monitoring dilakukan untuk memperoleh capaian keberhasilan program.

d. Tahap pendampingan.

Pendampingan oleh Tim Peneliti dilakukan secara terus menerus sehingga dapat mengatasi permasalahan yang muncul hingga program dapat dimanfaat secara terus menerus.

e. Tahap evaluasi program.

Dengan mengevaluasi pelaksanaan program, Tim Peneliti dapat lebih menggali sumberdaya yang terdapat pada Mitra sehingga dapat meningkatkan pemahaman terhadap teknologi sistem penerangan listrik di lingkungan sekitar Pimpinan Cabang Pemuda Muhammadiyah Pulo Brayan Darat. Pada tataran pelaksanaan di lapangan, pelaksanaan evaluasi yang dilakukan oleh Tim Peneliti tentunya melibatkan pengurus yang ada. 
f. Tahap akhir penyusunan laporan pengabdian.

Penyusunan laporan dilakukan dengan mengumpulkan data dan informasi secara terperinci terhadap pelaksanaan pengabdian yang dilakukan. Laporan tersebut dilaporkan kepada Politeknik Negeri Medan sebagai penanggungjawab pengabdian yang dilakukan.

g. Publikasi hasil Pengabdian Masyarakat

Pengabdian yang dilaksanakan untuk penyebarluasan teknologi terkini sehingga menjadi acuan pelaksanaan bagi masyarakat sekitar. Publikasi yang dilakukan dapat melalui media live streaming dan sosial media yang ada.

\subsection{Partisipasi Mitra}

Pelaksanaan pengabdian ini melibatkan seluruh unsur Pemuda masyarakat yang ada. Tahap awal pengabdian dilakukan survei awal berupa wawancara serta penggalian data mengenai kondisi yang ada dan hal yang sangat diperlukan. Penyusunan tim input data yang melibatkan pengurus akan memudahkan pelaksanaan progam pengabdian. Berdasarkan hal tersebut diharapkan data yang ada diperoleh secara lengkap. Pada aktifitas sosialisasi mengenai Penerapan teknologi sistem penerangan serta perhitunga tarif dasar listrik tahun 2020 dan kerangka acuan program pengabdian dimaksudkan agar masyarakat mengetahui program tersebut.

\section{Pembahasan}

Pelaksanaan pengabdian ini melibatkan seluruh unsur Pemuda masyarakat yang ada. Tahap awal pengabdian dilakukan survei awal berupa wawancara serta penggalian data mengenai kondisi yang ada dan hal yang sangat diperlukan. Penyusunan tim input data yang melibatkan pengurus akan memudahkan pelaksanaan progam pengabdian. Berdasarkan hal tersebut diharapkan data yang ada diperoleh secara lengkap. Pada aktifitas sosialisasi mengenai Penerapan teknologi sistem penerangan serta perhitungan tarif dasar listrik tahun 2020 dan kerangka acuan program pengabdian dimaksudkan agar masyarakat mengetahui program tersebut.
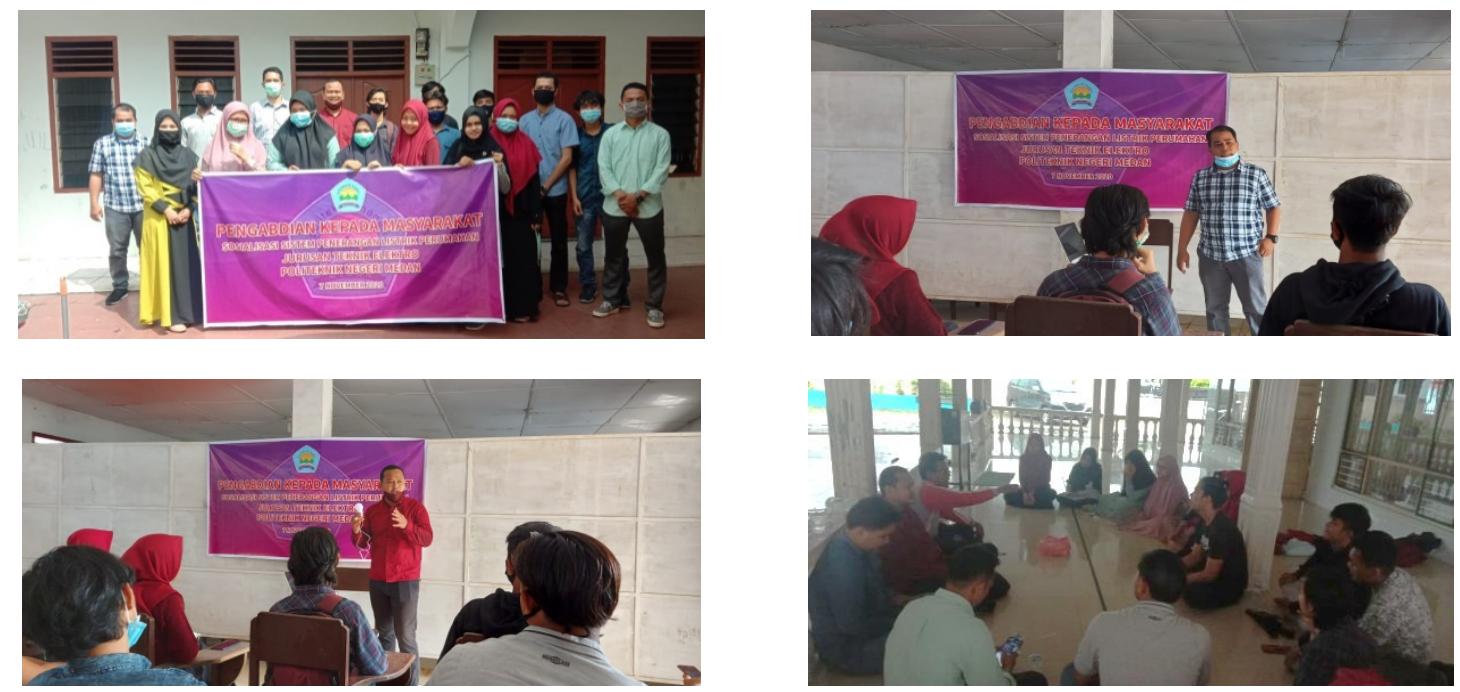

Gambar 2. Pelaksanaan Kegiatan Pengabdian dalam Penyampaian Materi Sosialisasi 


\section{Simpulan}

Pelaksanaan pengabdian ini melibatkan seluruh unsur Pemuda masyarakat yang ada. Tahap awal pengabdian dilakukan survei awal berupa wawancara serta penggalian data mengenai kondisi yang ada dan hal yang sangat diperlukan. Penyusunan tim input data yang melibatkan pengurus akan memudahkan pelaksanaan progam pengabdian. Berdasarkan hal tersebut diharapkan data yang ada diperoleh secara lengkap. Pada aktifitas sosialisasi mengenai Penerapan teknologi sistem penerangan serta perhitunga tarif dasar listrik tahun 2020 dan kerangka acuan program pengabdian dimaksudkan agar masyarakat mengetahui program tersebut.

\section{Referensi}

Adin Sudirman, Asep Saepuloh. 2007. Kajian Intensitas Cahaya Pada Sistem Penerangan RsgGas. Buletin Pengelolaan Reaktor Nuklir. Vol. 4 No. 1, April 2007 : 1-9.

Fathir Rizqi. 2017. Analisa Efisiensi Belajar Menggunakan Beberapa Jenis Lampu. Universitas Muhammadiyah Surakarta.

Jimy Harto Saputro, Tejo Sukmadi, and Karnoto. 2013. Analisa Penggunaan Lampu Led Pada Penerangan Dalam Rumah. TRANSMISI. 15. (1). 2013.

Moethia Faridha, Ifan, 2016. Studi Komparasi Lampu Pijar, Led, Lhe Dan Tl Yang Ada Dipasaran Terhadap Energi Yang Terpakai. ISSN 2502-4922 Jurnal Teknik Mesin UNISKA Vol. 02 No. 01 November 2016.

Siti Anisah, Amani Darma Tarigan. Analisis Pemanfaatan Lampu Panerangan Hemat Enargi Pada Rumah Tinggal Di Desa Lau Gumba Berastagi Kabupaten Tanah Karo Provinsi Sumatera Utara. Universitas Pembangunan Panca Budi Medan.

PUIL 2000. Penerbit Yayasan PUIL. Jakarta.

https://web.pln.co.id/pelanggan/tarif-tenaga-listrik

\section{Ucapan Terima Kasih}

Terima kasih kepada Politeknik Negeri Medan yang telah memberikan izin dalam pelaksanaan PKM di tahun 2020. Selanjutnya kepada Pimpinan Cabang Pemuda Muhammadiyah Pulo Brayan Darat sebagai Mitra pada pengabdian ini.

\section{Copyrights}

Copyright for this article is retained by the author(s), with first publication rights granted to the journal.

This is an open-access article distributed under the terms and conditions of the Creative Commons Attribution license (http://creativecommons.org/licenses/by/4.0/) 